\title{
Актуальные направления селекции на улучшение питательной ценности клубней картофеля
}

\author{
Current trends in breeding to improve nutritional value of potato tubers
}

\author{
Симаков Е.А., Анисимов Б.В., Жевора С.В., Митюшкин \\ А.В., Журавлев А.А., Митюшкин Ал-р В., Гайзатулин А.С.
}

\section{Аннотация}

Цель работы: изучение эффективности использования доноров и родительских линий при реализации важнейших направлений селекции на основе оптимальных вариантов гибридизации и отбора селекционно ценных генотипов для улучшения питательной ценности клубней новых перспективных сортов картофеля. Материал исследований: сортообразцы из коллекции ВИР и ВНИИКХ, созданные на основе межвидовой гибридизации и последующих возвратных скрещиваний с сортами S. tuberosum. Исследования проводили в 2008-2018 годах на экспериментальных базах ВНИИКХ «Коренево» и «Пышлицы» Московской области. В результате изучения гибридов выявлено трансгрессивное расщепление по крахмалистости клубней при накапливающих скрещиваниях родителей с крахмалистостью 18-19\%, существенно повышающее уровень этого признака в потомстве, слабо коррелирующего с урожайностью. Поэтому идентификация генотипов, сочетающих оба признака, отмечена только на уровне средней популяционной, совпадающей со средней крахмалистостью родителей, а результативность отбора низкокрахмалистых форм значительно выше, поскольку снижение уровня проявления признака не имеет отрицательной корреляции с урожайностью. Среди гибридов с высокой крахмалистостью (19-21\%) клубней отмечены генотипы, содержащие от 50,6 до 61,5\% крупных крахмальных гранул (>60 мкм), что обусловливает вероятность отбора форм с высоким качеством крахмала. Установлена высокая корреляционная связь $(+0,897)$ содержания белка в клубнях родительских форм со средней белковостью потомства, что подтверждает наличие контроля этого признака аддитивно действующими полигенами. При этом в процессе естественного мейотического рекомбиногенеза в гибридных популяциях наблюдается увеличение белковости клубней гибридов в крайних классах вариационного ряда до 3,5-3,9\%, что превышает содержания белка контрольных образцов на 1,5$1,9 \%$. При измерении антиоксидантной активности (AOA) copтообразцов коллекционного питомника установлен ее высокий уровень (1032-1280 мг/кг) у гибридов с пигментированной окраской кожуры и мякоти клубней, отличающихся высоким содержанием каротиноидов и антоцианов, определяющих ее уровень. Среди гибридного потомства от скрещивания красно-фиолетовых и красноклубневых родительских форм отмечено на 9,7-12,0\% больше фенотипов с красно-фиолетовой окраской в сравнении с вариантами скрещивания одинаковых по окраске сортообразцов. Использование выделенных сортообразцов в качестве доноров комплекса хозяйственно полезных признаков позволяет ускорить селекционный процесс и сократить затраты на создание новых сортов картофеля с улучшенной питательной ценностью клубней.

Ключевые слова: картофель, селекция, питательная ценность, крахмалистость, белковость, антиоксиданты.

Для цитирования: Актуальные направления селекции на улучшение питательной ценности клубней картофеля / Е.А. Симаков Б.В. Анисимов, С.В. Жевора, А.В. Митюшкин, А.А. Журавлев, Ал-р. В. Митюшкин, А.С. Гайзатулин // Картофель и овощи. 2020. №2. С. 35-40. https://doi.org/10.25630/PAV.2020.18.2.008

\author{
Simakov E.A., Anisimov B.V., Zhevora S.V., Mityushkin A.V., \\ Zhuravlev A.A., Mityushkin Al-r V., Gaizatulin A.S.
}

\section{Abstract}

The purpose of the work: to study the effectiveness of using donors and parent lines in the implementation of the most important areas of selection based on optimal hybridization options and selection of breeding valuable gene types to improve the nutritional value of tubers of new promising potato varieties. The research material: varietal samples from the collection of VIR and Lorch Potato Research Institute, created on the basis of interspecific hybridization and subsequent return crosses with varieties of S. tuberosum. The research was carried out in 20082018 at the experimental bases of Lorch Potato Research Institute "Korenevo" and "Pyshlitsy" Moscow region. As a result of studying hybrids transgressive cleavage of tubers by starchiness was found in accumulating crosses of parents with a starchiness of $18-19 \%$, which significantly increases the level of this trait in the offspring, which is rarely correlated with yield. Therefore, identification of genotypes, combined the two features observed only at the level of the average population, coinciding with the average starch content parents, and the effectiveness of the selection low-starchy forms is much higher, since the decrease in the level of a trait has negative correlation with productivity. Hybrids with high starchiness (19-21\%) of tubers, genotypes containing from 50.6 to $61.5 \%$ of large starch granules $(>60 \mathrm{mkm})$ are measured, which makes it possible to select forms with a high starch content. A high correlation $(+0.897)$ of the protein content in tubers of the parent forms with the average protein content of the offspring was established, which confirms the presence of control of this feature by additive acting polygens. At the same time, during natural meiotic recombination in hybrid populations, the protein content of hybrid tubers in the extreme classes of the variation series increases to $3.5-3.9 \%$, which exceeds the protein content of control samples by $1.5-1.9 \%$. When measuring the antioxidant activity (AOA) of collectible nursery cultivars, its high level (1032-1280 mg/kg) was established in hybrids with pigmented skin and pulp of tubers, characterized by a high content of carotenoids and anthocyanins that determine its level. Among the hybrid offspring from the crossing of red-purple and red-tuberous parent forms, the largest number of phenotypes with red-purple color was noted, exceeding by $9.7-12 \%$ other variants. The use of selected variety samples as donors of a complex of economically useful features allows speeding up the selection process and reducing the cost of creating new potato varieties with improved nutritional value of the tubers.

Key words: potatoes, selection, nutritional value, crunchiness, protein content, antioxidants.

For citing: Current trends in breeding to improve nutritional value of potato tubers. E.A. Simakov, B.V. Anisimov, S.V. Zhevora, A.V. Mityushkin, A.A. Zhuravlev, Al-r V. Mityushkin, A.S. Gaizatulin. Potato and vegetables. 2020. No2. Pp. 35-40 (In Russ.). https://doi.org/10.25630/ PAV.2020.18.2.008 
$\mathrm{C}$ егодня важное значение картофеля как полноценного и достаточно доступного продукта питания в полной мере оценено населением многих стран, что способствовало его широкому распространению по всем континентам [1]. При этом высокая питательная ценность картофеля обусловливается содержанием комплекса веществ, столь необходимых для здорового питания человека: крахмала, полноценного белка, небелковых соединений (свободные аминокислоты и амиды), органических кислот, сахара, минеральных веществ, витаминов, жиров и липидов [2, 3]. Однако в последние годы реализация селекционных программ по картофелю проводится с учетом новых требований потребителей, связанных с необходимостью улучшения качества питания в жизни человека - снижения калорийности пищи, повышения содержания полноценного белка, витаминов и антиоксидантов $[4,5]$. Учитывая изменившиеся требования к повышению качества продовольственного картофеля и целевому использованию урожая, селекционно-генетические исследования ВНИИКХ базируются на поиске и широком привлечении новых генетических источников, выделении доноров и родительских линий, проведении интрогрессивной гибридизации и анализе наследования хозяйственно полезных признаков в гибридном потомстве.

Условия, материал и методы исследования

В качестве объектов исследования использовали свыше 200 сортообраз- цов из коллекции ВИР и ВНИИКХ, созданных с использованием природных источников устойчивости из числа диких и культурных видов в результате межвидовой гибридизации и последующих возвратных скрещиваний с сортами S. tuberosum. На основе интрогрессии ценных генов от диких и культурных видов (S. chacoense, S. vernei, S. stoloniferum, S. demissum, S. andigenum) получены гибриды-беккроссы разных поколений с генами иммунитета к вирусам X, Y, полевой устойчивостью к фитофторозу и другим патогенам, которые оценивали в период 2008-2018 годов для идентификации доноров важнейших хозяйственно полезных признаков, обусловливающих, в том числе, и питательную ценность клубней картофеля. Для улучшения питательной ценности вновь создаваемого гибридного потомства в скрещивания включали свыше 70 доноров высокой крахмалистости, крупной фракции крахмальных гранул, содержания белка и антиоксидантов. В процессе исследований изучено более 2000 гибридных популяций от скрещиваний беккроссов высоких поколений, гибридов и сортов межвидового происхождения. Селекционные питомники закладывали в соответствии с методикой ВНИИКХ (2006) на экспериментальной базе «Пышлицы» Шатурского района Московской области. Крахмалистость определяли по удельному весу, а фракционный состав крахмальных гранул - безмикроскопным методом. Содержание белка в клубнях оценивали рефрактометрически, а антиоксидантную ак- тивность сортообразцов (АОА) - амперметрическим методом с использованием прибора «Цвет Яуза-01-АА». Генетический анализ гибридных популяций по хозяйственно полезным признакам проводили в первом клубневом поколении, выращивая не менее 100 генотипов. Экспериментальные данные подвергали математической обработке с использованием пакета прикладных программ «ПК АВ-Stat.V-1.1.».

\section{Результаты исследований}

При оценке крахмалистости клубней сортов и гибридов, проведенной в разные по метеоусловиям годы, установлено, что широкий диапазон изменчивости можно наблюдать в течение одного вегетационного периода при анализе гибридных популяций различного происхождения. Так, амплитуда варьирования крахмалистости в 6 гибридных популяциях в 2014 году, благоприятном для формирования признака, составляла 14,7-27,6\% (табл. 1). Это вполне согласуется с ранее полученными данными при анализе содержания крахмала в клубнях большой группы гибридных популяций различного генетического происхождения [6].

В неблагоприятных условиях для образования крахмала (избыточная влажность, слабая солнечная инсоляция, низкие температуры) широта варьирования признака резко уменьшалась, а нижняя граница изменчивости признака составляла 8,9\%. Следует отметить, что данный количественный признак контролируется серией доминантных аддитивно действующих генов (полигенов), которые наследуются по тетрасоми-

Таблица 1. Изменчивость крахмалистости клубней в гибридных популяциях картофеля в различных условиях вегетации, 2013-2014 годы

\begin{tabular}{|c|c|c|c|c|c|}
\hline $\begin{array}{c}\text { Происхождение } \\
\text { гибридной популяции }\end{array}$ & $\begin{array}{c}\text { Испытано } \\
\text { гибридов, шт. }\end{array}$ & $\begin{array}{c}\text { Средняя } \\
\text { крахмалистость, \% } \\
(\mathrm{X} \pm \mathrm{Sx})\end{array}$ & $\begin{array}{c}\text { Пределы } \\
\text { варьирования, \% } \\
\text { (min-max) }\end{array}$ & $\begin{array}{l}\text { Коэффициент } \\
\text { вариации (Cv) }\end{array}$ & $\begin{array}{c}\text { Отобрано гибридов } \\
\text { с крахмалистостью } \\
\geqslant 17 \%\end{array}$ \\
\hline \multicolumn{6}{|c|}{2013 год } \\
\hline 88.16/20 × Зарево & 154 & $14,0 \pm 0,75$ & $10,9-18,4$ & 19,11 & 20,8 \\
\hline Нида × Сатурна & 175 & $15,3 \pm 0,48$ & $12,2-18,2$ & 18,75 & 21,4 \\
\hline 1977-76 × Зарево & 172 & $16,2 \pm 0,49$ & $12,8-18,8$ & 16,41 & 24,6 \\
\hline Сантана $\times$ Инноватор & 153 & $14,9 \pm 0,36$ & $11,4-17,7$ & 20,72 & 22,9 \\
\hline 946-3 × Журавинка & 144 & $13,5 \pm 0,29$ & $8,9-16,9$ & 25,81 & 18,1 \\
\hline Сатурна $\times$ Наяда & 157 & $15,7 \pm 0,64$ & $10,4-16,5$ & 17,21 & 19,4 \\
\hline \multicolumn{6}{|c|}{2014 год } \\
\hline Фрителла × Зарево & 162 & $19,2 \pm 0,82$ & $16,2-27,6$ & 29,35 & 43,1 \\
\hline Кребелла × Адретта & 142 & $17,3 \pm 0,61$ & $14,7-20,4$ & 25,70 & 29,2 \\
\hline Адретта $\times$ Инноватор & 168 & $18,1 \pm 0,54$ & $15,9-21,2$ & 24,36 & 30,4 \\
\hline Никулинский × Зарево & 184 & $18,8 \pm 0,78$ & $15,6-22,3$ & 26,13 & 36,2 \\
\hline Фрителла × Адретта & 172 & $17,5 \pm 0,64$ & $14,5-22,0$ & 28,71 & 41,0 \\
\hline Чифтейн × Колетте & 138 & $16,9 \pm 0,49$ & $14,8-19,7$ & 26,26 & 39,1 \\
\hline $\mathrm{HCP}_{0,05}$ & & 0,72 & & & \\
\hline
\end{tabular}


Таблица 2. Оценка высококрахмалистых гибридов по размеру крахмальных гранул, 2013-2014 годы

\begin{tabular}{|c|c|c|c|c|}
\hline \multirow{2}{*}{$\begin{array}{c}\text { Происхождение } \\
\text { гибридов }\end{array}$} & \multirow{2}{*}{ Крахмалистость, \% } & \multicolumn{3}{|c|}{ Содержание крахмальных гранул по фракциям, \% } \\
\hline & & $\geqslant 60$ мКм & 40-59 мкм & $\leqslant 39$ мКм \\
\hline Кребелла × Адретта & 19,2 & 50,6 & 37,1 & 12,3 \\
\hline Фрителла × Адретта & 19,8 & 52,4 & 38,2 & 9,4 \\
\hline Адретта $\times$ Инноватор & 20,2 & 55,7 & 36,7 & 7,6 \\
\hline Никулинский $\times$ Зарево & 20,8 & 60,2 & 31,6 & 8,2 \\
\hline Фрителла × Зарево & 21,1 & 61,5 & 31,1 & 7,4 \\
\hline $\mathrm{HCP}_{0,05}$ & 0,59 & & & \\
\hline
\end{tabular}

ческому типу, свойственному автотетраплоидам, к которым принадлежит вид S. tuberosum [7].

В соответствии с выявленными закономерностями наследования признака, среди проанализированных родительских форм с крахмалистостью 17-18\%, оцененных по потомству от самоопыления, выделены генотипы, содержащие шесть доминантных аллелей (сорта Зарево, Адретта, Кребелла, Эффект и др.). При этом каждый аллель способствовал формированию в среднем 3,0-3,5\% крахмала. Гомозиготными по обоим локусам генотипами, содержащими 8 доминантных аллелей, оказались сорта Зарево и происходящий от него сорт Батя, крахмалистость которых в благоприятных условиях вегетации достигала 22-24\%. Однако уровень урожайности этих сортов оказался невысоким. Это результат отрицательной корреляции между крахмалистостью и урожайностью. Одновременно выявлено, что при скрещивании или самоопылении генотипов с крахмалистостью 18-19\%, в потомстве отмечается трансгрессивное расщепление по крахмалистости, присущее аддитивно действующим полигенам и характеризующееся появлением положительных и отрицательных трансгрессий. В селекционном процессе их использование возможно как в целях повышения уровня этого признака, так и его снижения. Накапливающие скрещивания высококрахмалистых родителей между собой существенно повышают уровень этого признака в потомстве, однако отрицательная корреляция с урожайностью ограничивает результативность отбора ценных рекомбинантов. Отбор генотипов, сочетающих оба признака, отмечается только на уровне средней популяционной, которая совпадает со средней крахмалистостью родителей. Наиболее эффективный метод повышения средней популяционной - подбор высококрахма- листых родительских форм, отличающихся генетической отдаленностью. В этом случае перекомбинация высокой крахмалистости и урожайности осуществляется за счет трансгрессивного рекомбиногенеза.

Поэтому успех селекции в направлении повышения содержания крахмала в клубнях определяется уровнем крахмалистости компонентов гибридизации. Селекция на качество картофельного крахмала. По результатам оценки гибридов с высокой крахмалистостью (19-21\%) установлено, что некоторые из них характеризуются крупными крахмальными зернами ( $\geqslant 60$ мкм), доля которых составляет более $50 \%$ (табл. 2). Это обусловливает возможность целенаправленной селекции генотипов с высоким качеством крахмала, что вполне согласуется с новыми фактами, подчеркивающими важность картофельного крахмала в повседневном питании человека. Неперевариваемый картофельный

Таблица 3. Изменчивость содержания белка в клубнях гибридных популяций картофеля, 2015-2016 годы

\begin{tabular}{|c|c|c|c|c|c|c|c|c|c|c|c|c|}
\hline \multirow{2}{*}{$\begin{array}{c}\text { Происхождение } \\
\text { гибридных } \\
\text { популяций }\end{array}$} & \multicolumn{2}{|c|}{$\begin{array}{c}\text { Содержание } \\
\text { белка в клубнях } \\
\text { родительских } \\
\text { форм }\end{array}$} & \multirow{2}{*}{$\begin{array}{l}\text { Испы- } \\
\text { тано } \\
\text { гиб- } \\
\text { ридов, } \\
\text { шт. }\end{array}$} & \multirow{2}{*}{$\begin{array}{c}\text { Среднее } \\
\text { содержа- } \\
\text { ние белка } \\
\text { в клубняях } \\
\text { гибрид- } \\
\text { ного по- } \\
\text { томства, } \\
(X \pm S \bar{x})\end{array}$} & \multirow{2}{*}{$\begin{array}{c}\text { Коэф- } \\
\text { фици- } \\
\text { ент ва- } \\
\text { риации, } \\
\text { (Cv) }\end{array}$} & \multicolumn{7}{|c|}{ Распределение гибридов по уровню содержания белка } \\
\hline & q & $\sigma^{2}$ & & & & $\begin{array}{c}\text { Менее } \\
1,00\end{array}$ & $\begin{array}{l}1,00- \\
1,39\end{array}$ & $\begin{array}{c}1,40- \\
1,79\end{array}$ & $\begin{array}{l}1,80- \\
2,19\end{array}$ & $\begin{array}{c}2,20- \\
2,59\end{array}$ & $\begin{array}{c}2,60- \\
2,99\end{array}$ & $\begin{array}{l}3,00 \text { и } \\
\text { более }\end{array}$ \\
\hline $\begin{array}{l}\text { Русский сувенир } \\
\times \text { Накра }\end{array}$ & 1,9 & 2,0 & 100 & $1,93 \pm 0,04$ & 20,9 & 1 & 6 & 17 & 20 & 30 & 22 & 4 \\
\hline $\begin{array}{l}\text { Памяти Рогачева } \\
\text { × Никулинский }\end{array}$ & 1,6 & 2,0 & 102 & $1,63 \pm 0,04$ & 22,7 & 8 & 10 & 29 & 35 & 17 & 3 & - \\
\hline $\begin{array}{l}\text { Антонина × } \\
\text { Василек }\end{array}$ & 1,9 & 2,0 & 101 & $1,92 \pm 0,05$ & 26,5 & 7 & 5 & 9 & 27 & 23 & 19 & 11 \\
\hline Крепыш × Накра & 1,1 & 1,5 & 105 & $1,53 \pm 0,06$ & 28,5 & 18 & 17 & 28 & 22 & 11 & 9 & - \\
\hline $\begin{array}{l}\text { Ирбитский } \\
\text { Фрителла }\end{array}$ & 1,0 & 1,5 & 104 & $1,21 \pm 0,03$ & 24,5 & 28 & 39 & 21 & 7 & 5 & 4 & - \\
\hline $\begin{array}{l}\text { Фрителла × } \\
\text { Накра }\end{array}$ & 2,2 & 2,0 & 100 & $1,47 \pm 0,04$ & 29,9 & 12 & 26 & 32 & 15 & 8 & 3 & 4 \\
\hline $\begin{array}{l}\text { Матушка } \times \text { Нику- } \\
\text { линский }\end{array}$ & 2,5 & 2,0 & 100 & $2,38 \pm 0,04$ & 16,7 & - & 3 & 2 & 5 & 17 & 34 & 39 \\
\hline $\begin{array}{l}\text { Василек × Сви- } \\
\text { танок Киевский }\end{array}$ & 2,5 & 1,5 & 100 & $1,73 \pm 0,04$ & 23,1 & 2 & 9 & 28 & 33 & 18 & 6 & 4 \\
\hline $\mathrm{HCP}_{0,05}$ & & & & 0,48 & & & & & & & & \\
\hline
\end{tabular}


Таблица 4. Частота встречаемости фенотипов с различной окраской клубней в гибридных популяциях картофеля, 2015-2016 годы

\begin{tabular}{|c|c|c|c|c|c|c|c|}
\hline \multirow{3}{*}{$\begin{array}{l}\text { Происхождение } \\
\text { гибридных } \\
\text { популяций } \\
\text { Роко × Леди Ро- } \\
\text { зетта }\end{array}$} & \multicolumn{2}{|c|}{$\begin{array}{c}\text { Окраска клубней } \\
\text { родительских форм }\end{array}$} & \multirow{3}{*}{$\begin{array}{c}\text { Оценено } \\
\text { Фенотипов, } \\
\text { шт. } \\
245\end{array}$} & \multirow{2}{*}{\multicolumn{4}{|c|}{ Количество фенотипов с различной окраской клубней, \% }} \\
\hline & 우닌 & $\hat{0}$ & & & & & \\
\hline & красная & красная & & красная/56,3 & желтая/37,2 & бежевая/6,5 & - \\
\hline $\begin{array}{l}\Gamma K 153-25 \times \text { Bora } \\
\text { Valley }\end{array}$ & синяя & синяя & 198 & синяя/58,6 & $\begin{array}{l}\text { красно-фиоле- } \\
\text { товая/21,7 }\end{array}$ & желтая/17,2 & бежевая/ 2,5 \\
\hline $\begin{array}{l}4634-8 \times \text { Фиоле- } \\
\text { товый }\end{array}$ & $\begin{array}{c}\text { красно-фиоле- } \\
\text { товая }\end{array}$ & $\begin{array}{l}\text { красно-фиоле- } \\
\text { товая }\end{array}$ & 174 & $\begin{array}{l}\text { красно-фиоле- } \\
\text { товая/57,5 }\end{array}$ & синяя/22,4 & желтая/18,4 & бежевая/3,4 \\
\hline Василек × Кураж & $\begin{array}{c}\text { красно-фиоле- } \\
\text { товая }\end{array}$ & красная & 205 & $\begin{array}{l}\text { красно-фиоле- } \\
\text { товая/68,3 }\end{array}$ & красная/19,1 & желтая/9,8 & бежевая/2,8 \\
\hline
\end{tabular}

крахмал в организме человека рас- отобрать генотипы с крахмалистосщепляется и всасывается доволь- тью до 8\%. В частности, низкокрахно медленно, поэтому картофельные малистые формы (6,7-8,5\%) отмечеблюда разрешается включать в диету ны также в популяциях от скрещивабольных сахарным диабетом [8].

Однако для диетических целей наиболее эффективно использовать низкокрахмалистые сорта, которые значительно снижают риск включения углеводов в рацион питания больных. Селекция в направлении низкой крахмалистости осуществляется значительно легче по сравнению с селекцией высококрахмалистых генотипов, поскольку снижение уровня проявления признака не имеет отрицательной корреляции с урожайностью. Поэтому эффективно использовать низкокрахмалистые родительские формы в скрещиваниях между собой при их подборе с учетом генетической отдаленности, так как в их потомстве легко ния среднеспелых и среднепоздних родительских форм. Однако низкая крахмалистость гибридов, как правило, связана с поздним сроком созревания и отбор таких образцов малоэффективен, так как они отличаются нестабильностью показателей и в оптимальных условиях вегетации могут иметь повышенную крахмалистость. Отбор низкокрахмалистых форм необходимо проводить в оптимальных условиях для формирования признака и оценивать потенциал отобранного генотипа по верхней границе крахмалонакопления.

Селекция картофеля на повышение содержания белка. Согласно данным наших исследований по изучению 24 гибридных популяций, из-

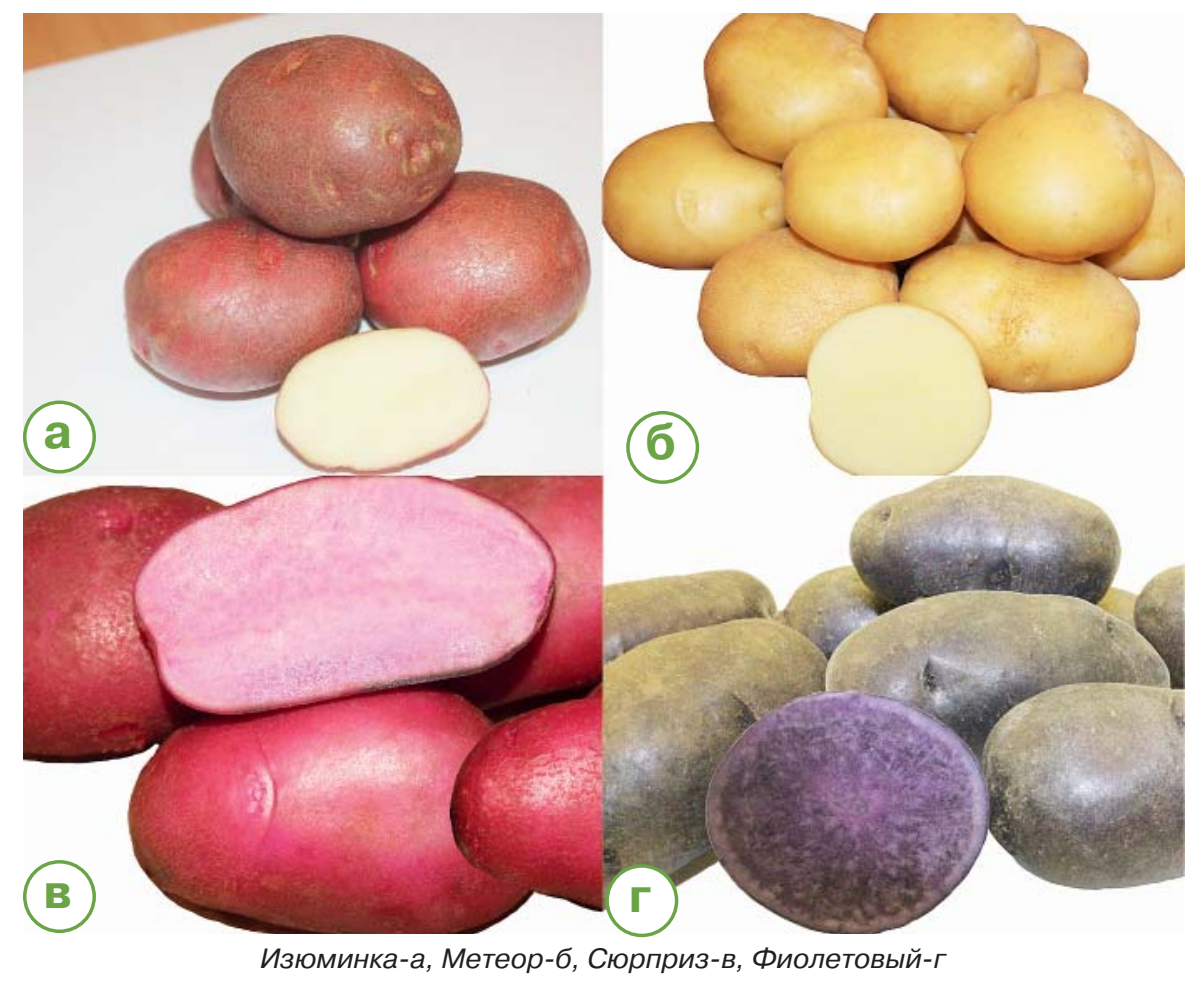

менчивость признака белковости в зависимости от влияния различных факторов довольно значительная и варьировала от 0,8 до $3,2 \%$ (табл. 3).

При этом степень изменчивости признака примерно в равных долях зависела от условий вегетационного периода и генотипических особенностей гибридных популяций. Одновременно установлена высокая положительная связь между содержанием белка в клубнях родительских форм и средней белковостью потомства (коэффициент корреляции $+0,897)$. Высокие значения коэффициента свидетельствуют об эффективности подбора родительских пар по фенотипу и подтверждают контролирование признака белковости аддитивно действующими полигенами, суммарный эффект которых определяет трансгрессивное расщепление признака в потомстве. Полученные данные показывают, что за счет естественного мейотического рекомбиногенеза в гибридных популяциях возможно увеличение белковости клубней у гибридов в крайних классах вариационного ряда до 3,5-3,9\%, что выше содержания белка в клубнях современных сортов на 1,5-1,9\%. Следует подчеркнуть, что поскольку частота встречаемости гибридов с повышенным содержанием белка невысокая, необходимо оценить 2-4 поколения гибридов от накапливающих скрещиваний при использовании отобранных генотипов в новых циклах гибридизации. Подбор по белковости также должен проводиться с учетом генетических различий и происхождения родительских форм.

Успешная селекция на повышенную белковость сдерживается из-за отсутствия экспресс-метода определения содержания белка в клубнях, который необходим для массовой оценки генотипов при большом объеме гибридных популяций, что поз- 
воляет выделить крайние варианты с высоким содержанием белка.

Селекция на повышенную антиоксидантную активность. Создание сортов картофеля, обладающих антиоксидантными свойствами, имеет важное социальное значение, так как доступность картофеля позволяет обеспечивать ценным диетическим продуктом широкие слои населения. Селекционная работа по созданию столовых диетических сортов ведется с начала нового тысячелетия и уже созданы сорта с высоким содержанием каротиноидов и антоцианов, отличающихся красной и фиолетовой мякотью клубней [9]. Указанные пигменты - основа биологических антиоксидантов, обладающих высокой способностью связывать свободные радикалы и ингибировать процесс их накопления в организме человека. В наших исследованиях для измерения суммарной антиоксидантной активности (АОА) использован амперметрический метод измерения с применением нового высокочувствительного прибора «Цвет-Яуза-01-АА», который позволяет проводить прямые количественные измерения исследуемых проб. При изучении уровня АОА у сортов коллекционного питомника картофеля показатели варьировали от 1080 мг/кг до 240 мг/кг, а среди гибридов - от 1280 до 300 мг/кг. По результатам исследований установлено, что, как правило, наиболее высоким содержанием антиоксидантов отличались сортообразцы с окрашенной кожурой и мякотью клубней. В частности, высокие показатели AOA имели сорта Кураж с красной окраской кожуры и желтой мякоти клубней (1080 мг/кг) и Василек с красно-фиолетовой окраской кожуры и белой с розовыми вкраплениями мякоти клубней (1052 мг/кг), антиоксидантная активность которых обусловлена наличием каротиноидов и антоцианов. Среди гибридов высокие показатели AOA также имели образцы с пигментированной окраской мякоти (1032-1280 мг/кг), указывающей на высокое содержание биологических антиоксидантов.

При анализе родословной гибридов с пигментированной окраской кожуры и мякоти клубней установлено, что при скрещивании родительских форм с красноокрашенными клубнями (генотип RE $\times$ RE) частота встречаемости красноклубневых форм в гибридном потомстве составила 56,3\% (табл. 4). Аналогичное расщепление выявлено также при скрещивании родителей с сине- и красно-фиолетовыми клубнями, имеющих генотип PE.

\section{Марий Эл: \\ поддержать фермеров}

В декабре Горномарийском районе Республики Марий Эл при партнерстве Агрохолдинга «Поиск» прошел научно-практический семинар для фермеров.

- На этой встрече мы подняли и обсудили вопросы о комплексе мер поддержки новых форм хозяйствования в республике, а именно - по развитию с.-х. потребительской кооперации, - говорит руководитель автономной некоммерческой организации «Центр компетенций в сфере с.-х. кооперации и поддержки фермеров Республики Марий Эл» Павел Валентинович Раевский. - А «Поиск» выступает партнером с.-х. потребительских кооперативов на территории Горномарийского района, в частности - кооператива «Мари Овощ», который занимается производством овощей в открытом грунте, а также закладывает производственные опыты с капустой белокочанной, огурцами открытого грунта.

Основная задача семинара - довести до с.-х. производителей ре-

При скрещивании разноцветных по окраске клубней сортообразцов (PE X $\mathrm{RE})$ в потомстве доля гибридов с красно-фиолетовой пигментацией гораздо выше, чем с красной, поскольку ген $\mathrm{P}$ подавляет проявление гена $\mathrm{R}$. Контролирование признака пигментации клубней доминантными независимыми генами обеспечивает получение успешных результатов по перекомбинированию признаков окраски с комплексом хозяйственно ценных показателей. Это подтвердили результаты оценки группы гибридов с синеи красно-фиолетовыми клубнями по уровню антиоксидантной активности. Характерно, что все эти гибриды происходят от скрещивания родительских форм со средними и высокими показателями АОА - от 432 до 600 мг/кг, что свидетельствует о накоплении антиоксидантов в потомстве при использовании родителей соответствующих уровней селектируемого признака. Следует отметить, что средние показатели AOA присущи большинству сортообразцов картофеля, поэтому для повышения содержания антиоксидантов в клубнях селекционных гибридов (до 2000-3000 мг/кг) необходим анализ потомства от разных типов скрещивания для изучения зако- зультаты производственных испытаний, оценки современных конкурентоспособных гибридов Агрохолдинга «Поиск», таких, как $F_{1}$ Универс, $F_{1}$ Герцогиня, $F_{1}$ Континент, $F_{1}$ Поиск 2018. Участники семинара подвели итоги летнего дня поля по огурцу, где хорошо зарекомендовали себя гибриды $F_{1}$ Энеж, 21, $F_{1}$ Атос. В ходе обсуждения решили провести в 2020 году научно-практический семинар по огурцу открытого грунта «День огурца в Марий Эл», где ожидается участие около 100 крестьянско-фермерских хозяйств. Были затронуты проблемы фитосанитарной обстановки в Гономарийском районе - развитие основных болезней и вредителей капусты, в т.ч. фузариоза и альтернариоза, килы. Основной вредитель - капустная моль. В прошедшем году хозяйства испытали баковые смеси с перспективными препаратами, показавшими высокую эффективность. В испытании - элементы технологии с использованием биологических методов защиты.

Участники встречи с нетерпением ждут научно-практический семинар «День огурца в Марий Эл», где им будет, чем поделиться с коллегами.

номерностей наследования признака антиоксидантной активности.

\section{Выводы}

В результате изучения свыше 200 сортообразцов из коллекции ВИР и ВНИИКХ, созданных на основе интрогрессии ценных генотипов от диких и культурных видов (S. chacoense, $S$. vernei, S. stoloniferum, S. demissum, S. andigenum), выделены более 70 гибридов-беккроссов и сортов с их участием для использования в качестве доноров комплекса хозяйственно полезных признаков, отличающихся, в том числе, питательной ценностью клубней. При скрещивании сортообразцов с крахмалистостью 18-19\% в потомстве отмечено трансгрессивное расщепление по крахмалистости, характеризующееся появлением как положительных (высококрахмалистых), так и отрицательных (низкокрахмалистых) генотипов. Среди гибридов с высокой крахмалистостью (19-21\%) клубней выявлены образцы, содержащие от 50,6 до 61,5\% крупных крахмальных гранул (>60 мкм), что подтверждает вероятность отбора генотипов с высоким качеством крахмала. Анализ гибридных популяций по белковости клубней показал, что увеличение этого показателя у генотипов 
в крайних классах вариационного ряда составляет 3,5-3,9\%, что превышает среднее содержание белка контрольных образцов на 1,5-1,9\%. При оценке суммарной антиоксидантной активности сортообразцов коллекционного питомника установлен ее высокий уровень (1032-1280 мг/кг) у гибридов с пигментированной окраской кожучаемости таких гибридов в потомстве от скрещивания родительских форм ры и мякоти клубней. Частота встре- только с синей, красной или краснофиолетовой окраской клубней сохрав то время как в скрещиваниях красно-фиолетовых и красноклубневых компонентов количество фенотипов с красно-фиолетовой окраской возрастало на 9,7-12,0\%. При этом контроль признака пигментации клубней доминантными независимыми генами обеспечивает успешное перекомбинирование окраски с комплексом хонялась практически на одном уровне,

зяйственно полезных признаков, среди которых и высокий уровень антиоксидантной активности. Использование выделенных сортообразцов в качестве доноров комплекса хозяйственно полезных признаков позволяет ускорить селекционный процесс и сократить затраты на создание новых сортов картофеля с улучшенной питательной ценностью клубней.

\section{References}

1.Horton D. La Papa: Produccion, comercializacion y programas // Co-publication of the Internacional Potato Center. Lima: Editorial Agropecuaria Hemisferio Sur, 2002. P. 1-270.

2. Haase N.U. Veränderungen der Inhaltsstoffe von Speisekartoffeen durch Lagerung und Verarbeitung // Kartoffelbau. 2002. V.53. №7. S. 284-289.

3.Шпаар Д. Картофель (выращивание, уборка, хранение). М.: ООО «ДЛВ Агродело», 2007. 457 с.

4.Landrum J., Bone R. Lutein, zeaxanthin and macular pigment // Arch. Biochem. Biophys. 2001. V. 385. Pp. 28-40.

5.Reyes L.F., Miller J.C., Cisneros-Zevallos L. Antioxidant capacity, anthocyanins and total phenolics in purple and red fleshed potato (Solanum tiberosum L.) genotypes // Amer. J. Potato Res. 2005. V. 82. Pp. 271-277.

6.Яшина И.М. Генетические основы селекции сортов картофеля на повышенную крахмалистость клубней // Генетика. 1982. Т. 18. №7. С. $1135-1143$.

7.Яшина И.М. Генетические аспекты использования исходного материала в селекции картофеля // Вопросы картофелеводства: сб. науч. тр. ВНИИКХ. М.: ВНИИКХ, 2004. С. 3-17.

8.Симаков Е.А., Яшина И.М., Склярова Н.П. Эффективность селекционного отбора при оценке гибридных популяций картофеля в различных эколого-географических условиях // Картофелеводство: сб. науч. тр. РУП НПЦ НАН Беларуси по картоф-ву и плодоовощ. Минск: Мерлит, 2003. Ч. І. С. 92-100.

9.Brawn C.R., Wrolstadt R., Durst C.P. Breeding studies in potato containing high concentraitions of anthocyanins // Am. potato J. 2003. V. 8. P. 241-250.

\section{Об авторах}

Симаков Евгений Алексеевич (ответственный за переписку), доктор с.-х. наук, профессор, зав. отделом экспериментального генофонда. E-mail:vniikh@mail.ru

Анисимов Борис Васильевич, канд. биолог. наук, зав. лабораторией сертификации и стандартизации

Жевора Сергей Валентинович, канд. с.-х. наук, директор

Митюшкин Алексей Владимирович, канд. с.-х. наук, зав. лабораторией селекции сортов для переработки

Журавлев Алексей Алексеевич, канд. с.-х. наук, с.н.с.

Митюшкин Александр Владимирович, канд. с.-х. наук, с.н.с.

Гайзатулин Александр Сергеевич, н.с.

ФГБНУ Всероссийский научно-исследовательский институт картофельного хозяйства им. А.Г. Лорха
1. Horton D. La Papa: Produccion, comercializacion y programas. Co-publication of the Internacional Potato Center.-Lima: Editorial Agropecuaria Hemisferio Sur, 2002. Pp. 1-270.

2. Haase N.U. Changes in the ingredients of Ware potatoes through storage and processing. 2002. V. 53. №7. Pp. 284-289.

3.Shpaar D. Potatoes (growing, cleaning, storage). Moscow: LLC Agrodelo, 2007. 457 p. (In Russ.)

4.Landrum J., Bone R. Lutein, zeaxanthin and macular pigment. Arch. Biochem. Biophys. 2001. V. 385. Pp. 28-40.

5.Reyes L.F., Miller J.C., Cisneros-Zevallos L. Antioxidant capacity, anthocyanins and total phenolics in purple and red fleshed potato (Solanum tiberosum L.) genotypes. Amer. J. Potato Res. 2005. V. 82. Pp. 271-277.

6.Yashina I.M. Genetic basis of breeding of potato varieties for high starch content of tubers. Genetics. 1982. V. 18. No7. Pp. 11351143 (In Russ.) potato breeding. Guestions of potato growing. Coll. of proc. Lorch pot. res. Moscow, 2004. Pp. 3-17 (In Russ.)

8.Simakov E.A., Yashina I. M., Sklyarova N. P. Efficiency of selection in evaluating hybrid potato populations in various ecological and geographical conditions. Potato growing. Coll. of proc. RUP NPC of the National Academy of Sciences of Belarus. Minsk: Merlit, 2003. V. I. Pp. 92-100 (In Russ.)

9.Brawn C.R., Wrolstadt R., Durst C.P. Breeding studies in potato containing high concentraitions of anthocyanins. Am. potato $\mathrm{J}$. 2003. V. 8. Pp. 241-250.

\section{Author details}

Simakov E.A. (author for correspondence), D. Sci. (Agr.), head of the experimental gene pool department. E-mail: vniikh@mail.ru

Anisimov B.V., Cand. Sci. (Biol.), head of the certification and standardization laboratory

Zhevora S.V., Cand. Sci. (Agr.), director

Mityushkin A.V., Cand. Sci. (Agr.), head of the laboratory for selection of varieties for processing

Zhuravlev A.A., Cand. Sci. (Agr.), senior research fellow

Mityushkin A.V., Cand. Sci. (Agr.), senior research fellow

Gaizatulin A.S., research fellow

Lorch Potato Research Institute
7.Yashina I.M. Genetic aspects of using the source material in

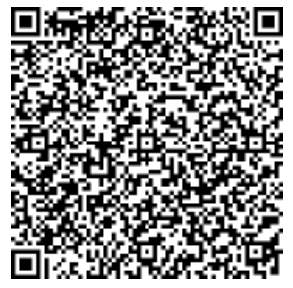

АДРЕС ДЛЯ ПЕРЕПИСКИ:

140153 Московская область, Раменский район, Д.Верея. стр. 500 В. В. Леунову Сайт: www.potatoveg.ru E-mail: kio@potatoveg.ru тел. 7 ( $(49646)$ 24-306, моб.+7(910)423-32-29, $+7(916) 677-23-42,+7(916) 498-72-26$

Журнал зарегистрирован в Министерстве Российской Федерации по делам печати, телерадиовещания и средств Свидетельство № 016257 ๑ Картофель и овощи, 2020 дуК РФ для публикации трудов аспирантов и сой
дунереративную базу данных Agris.

лей ученых степеней, в межИнформация об опубликованных статьях поступает в систему Российского индекс ( Сайт: www.рязанская-типография.рф E-mail: stolzakazov@mail.ryazan.ru. Телефон: +7 (4912) 44-19-36 